\title{
Perkawinan Tradisi Jujuran dalam Adat Bugis Perantau di Kutai Kartangera: Suatu Kajian Perbandingan dengan Hukum Islam
}

\author{
Eko Rial Nugroho ${ }^{1}$, Abdul Wahid \\ Fakultas Hukum Universitas Islam Indonesia \\ Correspondence email: 094100405@uii.ac.id, email: wahid.aira.aks@gmail.co.id
}

\begin{abstract}
Abstrak. Salah satu prosesi perkawinan adalah adanya maskawin atau mahar. Budaya pemberian maskawin berbeda antara satu daerah dengan daerah lain. Melekatnya tradisi jujuran di Kelurahan Kuala Samboja, Kecamatan Samboja, Kabupaten Kutai Kartanegara menimbulkan dampak-dampak social, di antaranya pria merasa tertahan untuk menikah. Padahal agama Islam memberikan kemudahan, agar masing-masing dapat menikmati hubungan yang halal dan baik. Berangkat dari latar keadaan tersebut, maka permasalahan yang dikaji ialah bagaimana perbandingan antara perkawinan tradisi jujuran dalam adat Bugis perantau di Kutai Kartanegara dengan perkawinan dalam Hukum Islam. Metode penelitian yang digunakan, ialah penelitian hukum normatif yang mendasarkan analisanya pada peraturan perundang-undangan yang terkait dengan permasalahan penelitian yang dikaji. Pendekatan dalam penelitian ini menggunakan pendekatan doktrinal. Sumber data penelitian yang digunakan, ialah sumber data sekunder. Hasil penelitian, pertama, tradisi jujuran adalah satu kesatuan dalam prosesi perkawinan adat masyarakat Kelurahan Kuala Samboja, Kecamatan Samboja, Kabupaten Kutai Kartanegara. Tradisi jujuran sebagai salah satu tolak ukur keberlanjutan rencana pernikahan. Prinsip pernikahan dalam tradisi jujuran adalah pernikahan tidak akan terjadi/terlaksana atau batal, apabila jujuran tidak dapat dipenuhi oleh calon mempelai laki-laki dan keluarganya. Kedua, pernikahan dalam Islam wajib memenuhi rukun dan syarat pernikahan. Wali nikah merupakan salah satu unsur penting dalam suatu akad nikah, karena pernikahan tidak sah tanpa adanya wali. Ada wali nikah menolak menikahkan anak perempuannya, dengan alasan tidak syar'i. Wanita yang akan menikah, tetapi tidak ada wali yang berhak menikahkannya, maka digunakan wali hakim. Kedudukan dan wewenang wali hakim sama dengan wali nashab atau wali yang berhak atas wanita yang berada di bawah perwaliannya.
\end{abstract}

Kata Kunci: hukum Islam, wali adhal, , jujuran, mahar

\begin{abstract}
One of the marriage processions is the presence of dowry. The culture of giving dowry differs from one region to another. The practice of the jujuran tradition in Kuala Samboja Village, Samboja District, Kutai Kartanegara District has social impacts, including men feeling restrained to get married. Whereas Islam provides convenience, so that each can enjoy a halal and good relationship. The problem is how is the comparison between marriage with the jujuran tradition in the Bugis nomads in Kutai Kartanegara with marriage in Islamic Law. The research method is a normative legal research that bases its analysis on legislation related to the research problems studied. The approach in this study is a doctrinal approach. Sources of research data are secondary data, namely data obtained from library research in the form of legal materials consisting of primary legal materials, secondary legal materials, tertiary legal materials. The results of the study, first, the jujuran tradition is a unity in the traditional marriage procession of the community of Kuala Samboja Village, Samboja District, Kutai Kartanegara Regency. The jujuran tradition is one of the benchmarks for the sustainability of marriage plans. The principle of marriage in the jujuran tradition is that marriage will not be carried out or canceled, if the jujuran cannot be fulfilled by the prospective bridegroom and his family. Secondly, marriage in Islam must fulfill the terms and conditions of marriage. The marriage guardian is one of the important elements in a marriage contract because marriage will no longer valid if it is done without guardian. There has been event that a marriage guardian refusing to marry his daughter on the grounds of contradicting the syara', a reason that are not justified by the law of shara 'which is referred to as adhal (reluctant) then there must be replaced by wali hakim. The position of the wali hakim in the process of the marriage as the guardian in lieu of the guardian of the prospective bride or replacing the position of the nashab guardian who, due to certain circumstances, cannot or does not want to become a marriage guardian for his daughter. The position and authority of the judge's guardian is the same as the nashab guardian or guardian of the bride lady who is under his guardianship.
\end{abstract}

Keywords: Islamic law, guardian adhal, jujuran, dowry.

\section{PENDAHULUAN}

Maha suci Allah dari segala kekurangan dan sifat buruk yang telah menciptakan makhluk hidup di muka bumi dengan berpasang-pasangan, baik dalam bentuk lelaki dan perempuan. Allah menjelaskan di dalam Al Quran Surat Yasin ayat 36 yang menyatakan Maha Suci Tuhan yang telah menciptakan pasanganpasangan semuanya, baik dari apa yang ditumbuhkan oleh bumi dan dari diri mereka maupun dari apa yang tidak mereka ketahui. ${ }^{2}$ Pernikahan disyariatkan agama sejalan dengan hikmah manusia diciptakan oleh Allah

${ }^{1}$ Dosen Fakultas Hukum Universitas Islam Indonesia

${ }^{2}$ Yayasan Penyelenggara Penterjemah Al-Qur'an, Yaqut Al-Qur'an dan Terjemahnya Juz 1 s/d 30, (Bandung: Penerbit Sinar Baru Algesindo, 2006), hlm.353. 
Eko Rial Nugroho dan Abdul Wahid, Perkawinan Tradisi Jujuran dalam Adat Bugis Perantau di Kutai Kartangera: Suatu Kajian Perbandingan dengan Hukum Islam

yaitu kemakmuran dunia dengan jalan terpeliharanya keturunan manusia. Para ulama sependapat bahwa nikah itu disyariatkan oleh agama. ${ }^{3}$ Tujuan dari disyariatkan perkawinan atas umat Islam, di antaranya adalah:

1. Untuk mendapatkan keturunan yang sah dan melanjutkan generasi yang akan datang. ${ }^{4}$

2. Menjaga diri dari setan, hubungan seksual yang diperintahkan antara suami dan istri dapat menjaga dirinya dari tipu daya setan, melemahkan keberingasan, mencegah keburukan-keburukan shahwat, memelihara pandangan, dan menjaga kelamin. ${ }^{5}$

3. Untuk mendapatkan keluarga bahagia yang penuh ketenangan hidup dan rasa kasih sayang;

4. Menghibur dan menenangkan jiwa.

Pernikahan berasal dari kata "nikah" yang berarti perjanjian antara laki-laki dan perempuan untuk bersuami istri. Nikah secara bahasa mempunyai arti hakiki dan majazi. Arti hakiki nikah ialah bergabung sedangkan arti majazi nikah ialah al watha' yang berarti bersetubuh. Pasal 1 Undang-Undang Nomor 1 Tahun 1974 tentang Perkawinan, menyebutkan bahwa perkawinan ialah ikatan lahir bathin antara seorang pria dengan seorang wanita sebagai suami istri dengan tujuan membentuk keluarga yang bahagia dan kekal berdasarkan Tuhan Yang Maha Esa. ${ }^{6}$ Pernikahan dalam pandangan Islam merupakan sunatullah dan sunnah Rasul. Sunatullah berarti sesuai dengan kodrat dan iradat Allah dalam menciptakan alam ini, sedangkan sunnah Rasul berarti suatu tradisi yang telah ditetapkan oleh Rasul untuk dirinya sendiri dan untuk umatnya. $^{7}$

Ikatan perkawinan dalam Hukum Islam disebut dengan mitsaqan ghalidzan, yaitu suatu ikatan yang kokoh untuk mentaati perintah Allah dan melaksanakannya merupakan ibadah. ${ }^{8}$ Salah satu dari prosesi pernikahan, adalah adanya maskawin atau mahar. Maskawin atau mahar ialah pemberian calon suami kepada calon istri sebelum, sesudah atau pada waktu berlangsungnya akad ${ }^{9}$ sebagai pemberian wajib yang tidak dapat diganti dengan lainnya. ${ }^{10}$ Dalam prakteknya, budaya pemberian maskawin berbeda antara satu daerah dengan daerah lain.

Perbedaan tersebut, salah satunya yang terjadi di Kelurahan Kuala Samboja, Kecamatan Samboja, Kabupaten Kutai Kartanegara. Di daerah tersebut, membedakan antara mahar dengan maskawin dengan alasan mereka mengamati bahwa mahar adalah sesuatu yang diberikan saat ijab kabul dan maskawin adalah hadiah bagi pengantin wanita. Daerah Kelurahan Kuala Samboja, Kecamatan Samboja, Kabupaten Kutai Kartanegara ini terdapat suku terdapat sebagian besar suku Banjar dan Bugis yang sangat menghormati dan melestarikan adat yang mereka miliki tidak terkecuali pada adat yang dikenal dengan istilah jujuran, yaitu suatu pemberian dari calon suami kepada calon istri, bukan hanya kewajiban tetapi pemberian jujuran harus maksimal dan sesuai keinginan pihak calon istri. ${ }^{11}$

Tradisi jujuran itu sendiri merupakan adat yang telah lama digunakan masyarakat di Kalimantan, terutama daerah Kalimantan Timur dan Kalimantan Selatan. Masyarakat Bugis perantauan yang telah lama bermukim di Kalimantan, khususnya di Kelurahan Kuala Samboja, Kecamatan Samboja, Kabupaten Kutai hlm. 282

${ }^{3}$ Abd. Shomad, Hukum Islam: Penormaan Prinsip Syari'ah dalam Hukum Indonesia, (Jakarta: Penerbit Kencana, 2010),

${ }^{4}$ Amir Syarifuddin. Hukum Perkawinan Islam di Indonesia: Antara Fiqh Munakahat dan Undang-Undang Perkawinan, (Jakarta: Penerbit Kencana, 2006), hlm. 46-47.

${ }^{5}$ Ali Yusuf As-Subki. Fiqih Keluarga: Pedoman Berkembang dalam Islam, (Jakarta: Penerbit AMZAH, 2010), hlm. 2527.

${ }^{6}$ Undang-Undang Perkawinan Nomor 1 tahun 1974 dan Kompilasi Hukum Islam, (Jakarta: Penerbit Pustaka Yustisia, 2009), hlm. 7

${ }^{7}$ Amir Syarifuddin, Garis-garis Besar Fiqh, (Jakarta: Penerbit Kencana, 2003), hlm. 76.

${ }^{8}$ Ahmad Ainani, 'Itsbat Nikah dalam Hukum Perkawinan di Indonesia”, artikel pada Jurnal Darussalam, No. 2, Vol. 10, (2010), hlm. 111-112.

${ }^{9}$ Mahar atau maskawin boleh dibayar kontan atau hutang, boleh dibayar sebagian terlebih dahulu dan sisanya kemudian menurut adat kebiasaan dalam masyarakat, tetapi sebaiknya maskawin dibayar terlebih dahulu meskipun hanya sebagian, berdasarkan hadis Rasulullah SAW. bahwa beliau pernah melarang Ali bin Abi Thalib untuk mengumpuli Fatimah sebelum memberikan sesuatu kepada Fatimah, kemudian Ali memberikan baju besinya. Dilihat dari H.A.S. Alhamdani, Risalah Nikah Hukum Perkawinan Islam, (Jakarta: Pustaka Amani, 1989), hlm. 110.

${ }^{10}$ Alhamdani, Risalah Nikah Hukum Perkawinan Islam, hlm. 110.

${ }^{11}$ Subli, "Problematika Penentuan Jujuran di Desa Muara Sumpoi Kecamatan Murung Kabupaten Murung Raya", artikel pada Jurnal Studi Agama dan Masyarakat, No. 2, Vol. 11, (2015), hlm. 226. 
Eko Rial Nugroho dan Abdul Wahid, Perkawinan Tradisi Jujuran dalam Adat Bugis Perantau di Kutai Kartangera: Suatu Kajian Perbandingan dengan Hukum Islam

Kartanegara akhirnya mengadopsi adat jujuran tersebut. Besar kecilnya jujuran bagi seorang gadis ditentukan oleh berbagai faktor yaitu di antaranya status sosial orang tua si gadis, tingkat pendidikan si gadis, dan pekerjaan. Besaran tersebut, karena memang dikehendaki orang tua si gadis sebagai biaya perkawinan dan bekal hidup bagi mempelai. ${ }^{12}$

Kebiasaan masyarakat suku Bugis di Kelurahan Kuala Samboja, Kecamatan Samboja, Kabupaten Kutai Kartanegara jujuran ini merupakan penentu berhasil atau tidaknya acara perkawinan nantinya. Ada yang menceritakan tentang batalnya perkawinan akibat pihak pria tidak bisa memenuhi permintaan besarnya jujuran. Pada masyarakat umum jumlah jujuran bisa juga diambil patokan dan besarnya jujuran kebanyakan orang di daerah tersebut. ${ }^{13}$

Melekatnya tradisi jujuran ini menimbulkan dampak-dampak social, antara lain pria memiliki kedudukan yang tinggi karena pria yang memberikan jujuran kepada wanita, namun ada juga pandangan bahwa kedudukan pria dalam tradisi jujuran merupakan pihak yang ditekan oleh wanita karena yang menentukan besarnya jumlah jujuran yang diminta adalah pihak wanita. ${ }^{14}$ Dampak sosial tersebut, membuat calon pengantin pria merasa tertahan untuk menikah dan nyali mereka kecil untuk membangun rumah tangga. Padahal, agama Islam meluaskan jalan dan kesempatan sebanyak mungkin pria dan wanita untuk menempuh hidup sebagai suami istri. Tujuannya yaitu agar masing-masing dapat menikmati hubungan yang halal dan baik. Hukum Islam sendiri senantiasa memberikan kemudahan dan menjauhi kesulitan dalam segala hal yang berhubungan dengan kebutuhan fitrah manusia termasuk dalam hal proses perkawinan.

Adakalanya perkawinan yang telah disepakati atau disetujui baik oleh calon mempelai laki-laki maupun calon mempelai wanita, ternyata masih ada pihak lain yang berkeberatan, yaitu wali. Pada kenyataannya, ada beberapa masalah atau halangan dalam melangsungkan perkawinan karena wali nikah yang berhak tidak mau atau menolak untuk menjadi wali bagi calon mempelai wanita dengan berbagai alasan. Ada wali nikah menolak menikahkan anak perempuannya, dengan alasan tidak syar'i, yaitu alasan yang tidak dibenarkan hukum syara' atau alasan yang dibenarkan oleh Islam. Alasan-alasan tersebut, antara lain: 1) anak gadis wali tersebut sudah dalam lamaran atau khitbah orang lain dan lamaran atau khitbah tersebut belum dibatalkan; 2) berbeda keyakinan dengan calon suami atau orang fasik (misalnya pezina dan suka mabuk); atau 3) mempunyai cacat tubuh yang menghalangi tugasnya sebagai suami. Wali yang menolak atau tidak bersedia menikahkan tersebut, dalam prakteknya disebut dengan istilah adhal (enggan).

Wali nikah merupakan salah satu unsur penting dalam suatu akad nikah, karena pernikahan tidak sah tanpa adanya wali. Wali nikah merupakan salah satu rukun nikah, sebagaimana disabdakan Rosulullah SAW bahwa "tidak ada nikah tanpa wali". Tanpa ijin dari wali, pernikahan dianggap tidak sahmeninggalkan salah satu rukun nikah yaitu tanpa adanya wali. Pernikahan atau perkawinan dalam pranata hukum Indonesia juga mewajibkan adanya wali, khususnya yang beragama Islam sebagaimana diatur dalam Pasal 19 dan Pasal 23 Kompilasi Hukum Islam dan Pasal 18 Peraturan Menteri Agama Nomor 11 Tahun 2007 tentang Pancatatan Nikah. ${ }^{15}$

\section{Perkawinan dengan tradisi jujuran dalam adat Bugis perantau di Kutai Kartanegara}

Pemberian jujuran pada masyarakat Kelurahan Kuala Samboja, Kecamatan Samboja, Kabupaten Kutai Kartanegara merupakan salah satu langkah awal yang dilakukan oleh laki-laki ketika akan melangsungkan perkawinan yang ditentukan setelah adanya proses lamaran. Apabila lamaran telah diterima, maka tahap selanjutnya adalah penentuan jujuran yang jumlahnya ditentukan terlebih dahulu oleh pihak wanita yang dilamar dan jika pihak laki-laki menyanggupi maka tahap perkawinan selanjutnya dapat segera

${ }^{12}$ Reni Wijaya, Warga Kelurahan Kuala Samboja, Samboja, Wawancara, 8 November 2017.

${ }^{13}$ Pada tanggal 1 Mei 2014 telah dilangsungkan prosesi perkawinan yaitu lamaran sekaligus pembayaran jujuran antara Muh. Akram Bin Muh. Amin Enre dan Siti Rahmatia Albar Binti Bahar J dengan jumlah jujuan yaitu Rp. 30.000.000,-, tempat tidur lengkap, lemari, meja rias, perlengkapan wanita lengkap, beras gula dan tepung. Hasil dari wawancaradengan Siti Rahmatia Albar. Dan pada tanggal 13 November 1993 telah dilangsungkan prosesi perkawinan yaitu lamaran sekaligus pembayaran jujuran antara Sudirman dan Chasanah dengan jumlah jujuran yaitu Rp. 500.000,-. Hasil dari wawancara dengan Reni Wijaya, 8 November 2017.

${ }^{14}$ Laila Ulfah Setiyawati, "Pandangan Hukum Keluarga Islam Terhadap Tradisi Jujuran pada Masyarakat Penajam Paser Utara Kalimantan Timur”, artikel pada Skripsi Fakultas Syari’ah dan Hukum UIN Sunan Kalijaga Yogyakarta, 2014, hlm. 7.

${ }^{15}$ Abd. Somad, Hukum Islam, (Jakarta: Penerbit Kencana Media Group, 2010), hlm. 275-276. 
Eko Rial Nugroho dan Abdul Wahid, Perkawinan Tradisi Jujuran dalam Adat Bugis Perantau di Kutai Kartangera: Suatu Kajian Perbandingan dengan Hukum Islam

dilangsungkan perkawinan. Dalam prakteknya, tradisi jujuran terkadang terjadi tawar-menawar jika pihak laki-laki keberatan dengan jumlah jujuran yang dipatok. Besar kecilnya jujuran bagi seorang gadis ditentukan oleh berbagai faktor, di antaranya status sosial orang tua si gadis, tingkat pendidikan si gadis, pekerjaan dan karena kehendkan orang tua si gadis sebagai biaya perkawinan dan bekal hidup bagi mempelai.

Tujuan diberikannya jujuran adalah bentuk penghormatan yang diberikan oleh calon mempelai pria kepada calon mempelai wanita. Pada masa sekarang ini, jujuran dalam masyarakat Bugis yang diberikan secara ekonomis sepertinya telah mengalami pergeseran paradigma, karena yang awalnya hanyalah sebagai bentuk penghormatan semata tetapi sekarang tujuan dari jujuran tersebut adalah sebagai peningkatan pamor dan menjaga rasa gengsi dalam pernikahan. Jujuran yang semakin besar diberikan, maka akan semakin meriah juga pesta perkawinan yang diselengggarakan sehingga akan menjadi suatu kebanggaan tersendiri di keluarga penganting perempuan. Bagi mereka yang melakukan pernikahan dengan syukuran yang sederhana, dirasa akan memalukan atau aib karena seperti ada sanksi sosial yang akan didapatkan. Sanksi sosial tersebut di antaranya, menjadi omongan atau gunjingan sesama tetangga.

Standar berapa besarnya jujuran yang harus dibayarkan oleh calon mempelai pria kepada calon mempelai wanita, memang tidak ada standar yang pasti namun besarnya jujuran yang harus dibayarkan ialah berdasarkan kesepakatan masing-masing pihak dalam proses lamaran. Masyarakat Bugis, pada saat proses lamaran tidak hanya sekedar datang dengan maksud untuk meminang, tetapi di dalam lamaran juga akan dilakukan proses negosiasi untuk menentukan jumlah jujuran yang akan dibayarkan oleh calon mempelai pria. Pihak keluarga pria yang akan membuka tawaran harga terlebih dahulu, biasanya besarnya jujuran dibuka dengan jumlah terkecil. Tujuannya adalah agar diharapkan nanti nilai jujuran yang disepakati tidak terlalu besar.

Pada proses lamaran, calon mempelai pria tidak langsung datang kepada pihak keluarga wanitanya tetapi diwakilkan keluarganya untuk datang meghadap kepada keluarga pihak calon mempelai wanita. Pada saat ini, jumlah jujuran terkecil yang biasa ditawarkan di daerah kelurahan Kuala Samboja pada masyarakat Bugis adalah sebesar Rp. 30.000.000 (tiga puluh juta rupiah). Hal ini sebagaimana diungkapkan oleh Ibu Rahmatia, ia berpendapat bahwa jumlah sebesar Rp. 30.000.000 (tiga puluh juta rupiah) sudah sangat kecil mengingat harga bahan pokok yang semakin meningkat. Pendapat lain diungkapkan oleh Ibu Mahdalena, ia menyatakan bahwa besarnya jujuran seharusnya tidak terlalu membebankan kepada pihak calon mempelai pria karena jika terlalu besar uang jujuran yang harus diberikan, besar kemungkinan akan menjadikan pernikahan tersebut ditunda maupun gagal.

Saat ini, tradisi jujuran di Kabupaten Kutai Kartanegara masih tetap ada dan semakin berkembang dengan sering berjalannya waktu. Jujuran menjadi suatu tradisi yang seakan-akan harus ada dalam setiap perkawinan. Beberapa responden yang melakukan perkawinan di Kabupaten Kutai Kartanegara yang telah diwawancarai oleh peneliti, mereka mengaku telah melakukan tradisi jujuran dalam perkawinan mereka. Jujuran sudah menjadi identitas di Kalimantan, khususnya di Kalimantan Timur. Sepanjang wawancara yang telah dilakukan oleh penulis, mereka yang melakukan perkawinan sudah pasti menggunakan jujuran karena bagi masyarakat bugis hal itu merupakan suatu yang wajib ada di dalam perkawinan. Bahkan ada perkawinan yang harus ditunda atau bahkan harus dibatalkan akibat uang jujuran yang terlalu besar sehingga dari pihak calon mempelai pria belum bisa memenuhi jujuran yang diminta tersebut. ${ }^{16}$

Beberapa faktor yang mempengaruhi besar kecilnya jujuran dalam masyarakat Bugis perantau, faktor paling utama adalah keturunan. Apabila calon mempelai wanitanya adalah keturunan bangsawan, maka dapat dipastikan akan besar juga jujurannya. Keturunan bangsawan tersebut, seperti marga yang menggunakan nama Andi. Bagi mereka wanita yang menggunakan nama depan tersebut, di dalam masyarakat Bugis mereka adalah wanita yang keturunan bangsawan. Oleh karena itu, maka jujuran yang diminta mereka akan besar. Kemudian akan dilihat lagi dari materi masing-masing pihak, semakin kaya mereka maka semakin besar juga jujuran yang akan diminta. Pada saat ini, faktor pendidikan dari calon mempelai wanita juga mempengaruhi. Besaran jujuran, akan sangat berbeda nilainya jika calon mempelai

${ }^{16}$ Potret di atas, akan berbeda halnya jika pernikahan itu tidak direncanakan, seperti jika calon mempelai wanitanya sudah hamil duluan maka tidak perlu jujuran dengan jumlah yang besar. Tujuannya adalah untuk menutupi aib dari keluarga masingmasing pihak, karena akan sangat malu jika hal tersebut diketahui oleh masyarakat luar atau tetangganya. 
Eko Rial Nugroho dan Abdul Wahid, Perkawinan Tradisi Jujuran dalam Adat Bugis Perantau di Kutai Kartangera: Suatu Kajian Perbandingan dengan Hukum Islam

wanita itu pendidikannya hanya lulusan SMA dibandingkan dengan mereka yang sudah lulusan sarjana. Di sisi lain, faktor harga bahan-bahan pokok juga mempengaruhi dalam penentuan jujuran. Jika harga bahanbahan pokok sedang naik, maka nilai jujuran pun ikut naik karena uang jujuran tersebut akan digunakan untuk keperluan dalam pesta perkawinan.

Proses pemberian jujuran dikenal dengan proses meantar jujuran, dalam prosesi ini pihak dari keluarga calon mempelai pria mengantarkan uang yang sebelumnya telah disepakati dalam prosesi lamaran kepada keluarga calon mempelai pria. Pihak calon mempelai pria biasanya diwakilkan oleh orang yang telah ditunjuk untuk melakukan prosesi penyerahan tersebut dan begitu juga dari pihak calon mempelai wanitanya. Proses di dalam meantar jujuran ini juga tidak hanya menyerahkan sejumlah uang, tetapi juga memberikan sejumlah peralatan lainnya seperti make up, pakaian, dan perabotan tertentu seperti kasur, bantal dan guling. Prosesi meantar jujuran ini biasanya hanya dihadiri oleh keluarga dan kerabat terdekat saja dari masing-masing kedua calon mempelai, kemudian prosesi tersebut diakhiri dengan jamuan sederhana dari pihak wanita.

Prosesi sebelum menikah di atas, di dalam agama Islam dikenal dengan namanya khitbah yang diartikan sebagai suatu langkah pendahuluan untuk melangsungkan perkawinan. Ulama fiqh mendefinisikan khitbah yaitu pernyataan keinginan pihak laki-laki kepada pihak wanita tertentu untuk mengawininya dan pihak wanita menyebarluaskan berita peminangan ini. Keinginan tersebut disampaikan dengan bahasa yang tepat dan jelas, tetapi pernyataan keinginan tersebut bisa juga disampaikan dalam bentuk sindiran. ${ }^{17}$

Agama Islam mengajarkan sebelum terjadinya akad nikah, calon mempelai pria dan wanita harus saling mengenal. Mengenal di sini maksudnya bukan hanya sekedar mengetahui tetapi juga memahami dan mengerti akan kepribadian masing-masing. Hal ini dipandang penting karena kedua mempelai akan mengikatkan diri dalam sebuah perkawinan, dan membentuk keluarga yang dimaksudkan keka" tanpa adanya perceraian. Atas hal itu, maka peminangan sangat dianjurkan oleh Rasulullah SAW sebelum melaksanakan perkawinan: sebagaimana sabda Rasul yang artinya: "Apabila seorang diantara kamu meminang seorang perempuan, jika ia dapat melihat apa yang dapat mendorongnya semakin kuat untuk menikahinya, maka laksanakanlah (HR Ahmad dan Abu Daud).

Perspektif Islam, peminangan lebih mengacu untuk melihat kepribadian calon mempelai wanita seperti ketakwaan, keluhuran budi pekerti, kelembutan dan ketulusannya. Yusuf Qardawi menyatakan bahwa jika pria diharuskan menyelidiki calon istrinya, wanita dan keluarganya pun hendaknya melakukan hal yang sama. Apabila datang pelamar, tidak pantas jika pertanyaan utamanya anak siapa. Tidak layak juga jika calon mempelai wanita hanya melihat apa yang dimiliki laki-laki, baik harta dan kedudukannya. Calon mempelai wanita dan keluarganya harus melihat bagaimana ahlak, ketakwaan dan hubungannya dengan Tuhan dan manusia. ${ }^{18}$

Prinsip yang dipegang kuat dalam tradisi adat jujuran adalah "tidak ada jujuran, maka tidak ada perkawinan". Jujuran bersifat wajib, bahkan apabila tidak menggunakan jujuran dianggap sebagai penghinaan bagi masyarakat adat tersebut. Implikasi hukum adanya jujuran ini adalah, di antaranya:

1. Apabila besaran jujuran yang diminta calon mempelai wanita dan keluarganya tidak dapat dipenuhi oleh calon mempelai laki-laki, maka kebanyakan calon mempelai wanita dan keluarganya lebih memilih untuk menunda hingga membatalkan atau tidak meneruskan sampai proses perkawinan. Hal ini kebanyakan terjadi ketika jujuran yang diminta terlalu besar di luar kemampuan dari calon mempelai laki-laki;

2. Apabila calon mempelai laki-laki dan wanita sudah saling mencintai dan ternyata besaran jujuran yang diminta calon mempelai wanita dan keluarganya tidak dapat dipenuhi oleh calon mempelai laki-laki, maka calon mempelai wanita secara diam-diam (tanpa sepengetahuan keluarga calon mempelai wanita) membantu calon mempelai laki-laki agar dapat memenuhi kewajiban jujuran yang ditentukan oleh calon mempelai wanita dan keluarganya;

3. apabila calon mempelai laki-laki dan calon mempelai wanita sudah saling mencintai, namun terhalang masalah jujuran yang diinginkan dari keluarga calon mempelai wanita, sehingga calon mempelai lakilaki tidak sanggup memenuhi keinginan tersebut, maka baik calon mempelai laki-laki dan calon mempelai wanita "sepakat" memilih "kawin lari", pergi ke daerah lain. Mereka melangsungkan

${ }_{17}^{17}$ Aminur Nuruddin dan Azhari Akmal Tarigan, Hukum Perdata Islam di Indonesia, (Jakarta: Kencana, 2004 ), hlm. 82.

${ }^{18}$ Aminur Nuruddin dan Azhari Akmal Tarigan, Hukum Perdata Islam di Indonesia., hlm. 85. 
Eko Rial Nugroho dan Abdul Wahid, Perkawinan Tradisi Jujuran dalam Adat Bugis Perantau di Kutai Kartangera: Suatu Kajian Perbandingan dengan Hukum Islam

pernikahan di daerah lain tersebut tanpa menggunakan tradisi adat jujuran dan memilih menggunakan hukum Islam;

4. Bagi calon mempelai laki-laki dan calon mempelai wanita yang sudah saling mencintai namun terhalang oleh jujuran, mereka berdua melakukan perbuatan yang tidak baik. Penyebab mereka berdua melakukan perbuatan yang tidak baik, karena pergaulan bebas yang saat ini berkembang pesat dan mengakibatkan calon mempelai wanita hamil di luar nikah. Implikasinya orang tuanya menanggung malu atas perbuatan tidak baik yang dilakukan anak-anak mereka. Agar kehamilannya anak mereka tidak diketahui oleh tetangga atau masyarakat sekitarnya, maka mau tidak mau orang tua segera menikahkan mereka tanpa memikirkan besaran nilai jujuran.

Berdasarkan uraian di atas dapat disimpulkan bahwa jujuran dalam perkawinan adat Bugis perantau di Kutai Kartanegara, merupakan satu kesatuan dari prosesi perkawinan adat yang menjadi tolak ukur keberlanjutan rencana pernikahan. Apabila jujuran tidak dapat dipenuhi, maka secara prinsip tidak akan ada atau tidak terjadi pernikahan.

\section{Perkawinan dalam Hukum Islam (UU Perkawinan dan KHI)}

UU Perkawinan, mendefinisikan perkawinan ialah ikatan lahir batin antara seorang pria dengan seorang wanita sebagai suami isteri dengan tujuan membentuk keluarga, rumah tangga yang bahagia dan kekal berdasarkan Ketuhanan Yang Maha Esa". Kompilasi Hukum Islam sendiri mendefinisikan perkawinan adalah akad yang sangat kuat atau mitsaqan ghalidzan untuk mentaati perintah Allah dan dalam melaksanakannya merupakan ibadah. Kata mitsaqan ghalidzan ini dari firman Allah SWT, dalam Surat AnNisâ (4): 21 yang artinya:

"Bagaimana kamu akan mengambil mahar yang telah kamu berikan pada isterimu, padahal sebagian kamu telah bergaul (bercampur) dengan yang lain sebagai sebagai suami-isteri. Dan mereka (isteriisterimu) telah, mengambil dari kamu perjanjian yang kuat (mitsaqan ghalidzan).”

Tujuan perkawinan menurut Undang-Undang Perkawinan adalah membentuk keluarga atau rumah tangga yang bahagia dan kekal. Untuk itu suami istri perlu saling membantu dan melengkapi, agar masingmasing dapat mengembangkan kepribadiannya membantu dan mencapai kesejahteraan spiritual dan material. ${ }^{19}$ Tujuan perkawinan tersebut tentu sangat ideal, selain tidak hanya dari lahirnya tetapi juga dari persatuan bathin di antara suami dan isteri yang ditujukan untuk membina suatu keluarga atau rumah tangga yang kekal dan bahagia bagi keduanya dan tentunya sesuai dengan kehendak Tuhan Yang Maha Esa. Ikatan lahir bathin tersebut haruslah berjalan beriringan, artinya tidak cukup dengan adanya ikatan lahir atau ikatan bathin karena dengan adanya keserasian antara keduanya maka akan membentuk suatu pondasi yang kuat dalam membentuk dan membina keluarga yang bahagia dan kekal. ${ }^{20}$ Tujuan perkawinan selaras dengan yang disebutkan dalam Pasal 3 Kompilasi Hukum Islam yang menyebutkan: "Perkawinan bertujuan untuk mewujudkan kehidupan rumah tangga yang sakinah mawadah dan rahmah."

Selain tujuan perkawinan, hukum Islam juga mengatur berkenaan dengan rukun perkawinan. Pada prinsipnya, rukun merupakan sesuatu yang mesti ada yang menentukan sah dan tidaknya suatu pekerjaan (ibadah). Syarat merupakan sesuatu yang mesti ada, yang menentukan sah dan tidaknya suatu pekerjaan (ibadah) tetapi sesuatu itu tidak termasuk dalam rangkaian pekerjaan itu sendiri. Sehingga sah suatu pekerjaan (ibadah) yang memenuhi rukun dan syarat.

Jumhur ulama sepakat bahwa rukun perkawinan terdiri atas: a). Adanya calon suami dan istri yang akan melakukan perkawinan; b). Adanya wali dari pihak calon pengantin wanita; c). Adanya dua orang saksi; d). Shigat akad nikah. KHI mengatur rukun nikah dalam Pasal 14 sebagai berikut: a). Calon suami; b). Calon istri; c). Wali nikah; d). Dua orang saksi; dan c). Ijab dan kabul. Syarat-syarat yang harus

${ }^{19}$ Badan Penelitian dan Pengembangan HAM Kementrerian Hukum dan HAM RI, Implementasi Undang-Undang Nomor 1 Tahun 1974 tentang Perkawinan, Dalam Rangka Perlindungan Hak Asasi Perempuan dan Anak dalam Hukum Nasional dan Kovenan Internasional, (Jakarta: Pohon Cahaya, 2011), hlm. 24.

${ }^{20}$ Badan Penelitian dan Pengembangan HAM Kementrerian Hukum dan HAM RI, Implementasi Undang-Undang Nomor 1 Tahun 1974 tentang Perkawinan, Dalam Rangka Perlindungan Hak Asasi Perempuan dan Anak dalam Hukum Nasional dan Kovenan Internasional, (Jakarta: Pohon Cahaya, 2011), hlm. 24. 
Eko Rial Nugroho dan Abdul Wahid, Perkawinan Tradisi Jujuran dalam Adat Bugis Perantau di Kutai Kartangera: Suatu Kajian Perbandingan dengan Hukum Islam

dilaksanakan sebelum pihak melangsungkan perkawinan terbagi atas syarat materil dan formil. Syarat materil adalah mengenai diri pribadi calon suami istri, sedangkan syarat formil adalah mengenai formalitas atau prosedur yang harus diikuti oleh calon suami istri sebelum maupun pada saat dilangsungkannya perkawinan. ${ }^{21}$ Pasal 2 ayat (1) menyatakan perkawinan adalah sah, apabila dilakukan menurut hukum masing-masing agamanya dan kepercayaannya itu. Pasal 2 ayat (2) menyatakan tiap-tiap Perkawinan dicatat menurut peraturan perundang-undangan yang berlaku.

Pada dasarnya, sahnya suatu perkawinan menurut undang-undang ialah apabila dilaksanakan menurut hukum masing-masing agama dan kepercayaan setiap orang yang akan melangsungkan perkawinan, setelah sah menurut agama dan kepercayaannya itu barulah Perkawinan tersebut dicatat untuk mendapatkan pengakuan dari negara. ${ }^{22}$

Syarat materil terbagi menjadi 2 (dua), yaitu syarat materil umum yang berlaku bagi pernikahan pada umumnya dan syarat materil khusus bagi pernikahan tertentu. Syarat materil umum diatur dalam Pasal 6 Undang-Undang tentang Perkawinan, yaitu:

1. Perkawinan didasarkan atas persetujuan kedua calon mempelai. ${ }^{23}$

2. Untuk melangsungkan perkawinan seorang yang belum mencapai umur 21 (duapuluh satu) tahun harus mendapat izin kedua orang tua.

3. Dalam hal seorang dari kedua orang tua meninggal dunia atau dalam keadaan tidak mampu menyatakan kehandaknya, maka izin yang dimaksud ayat (2) pasal ini cukup diperoleh dari orang tua yang masih hidup atau dari orang tua yang mampu menyatakan kehendaknya.

4. Dalam hal kedua orang tua telah meninggal dunia atau dalam keadaan tidak mampu untuk menyatakan kehendaknya, maka izin diperoleh dari wali orang yang memelihara atau keluarga yang mempunyai hubungan darah dalam garis keturunan lurus keatas selama mereka masih hidup dalam keadaan menyatakan kehendaknya.

5. Dalam hal ada perbedaan antara orang-orang yang dimaksud dalam ayat (2), (3) dan (4) pasal ini, atau salah seorang atau lebih diantara mereka tidak menyatakan pendapatnya, maka Pengadilan dalam daerah tempat tinggal orang yang akan melangsungkan perkawinan atas permintaan orang tersebut dapat memberikan ijin setelah lebih adhulu mendengar orang-orang yang tersebut dalam ayat (2), (3) dan (4) dalam pasal ini;

6. Ketentuan tersebut ayat (1) sampai (5) pasal ini berlaku sepanjang hukum masing-masing agamanya dan kepercayaannya itu dari yang bersangkutan tidak menentukan lain.

Undang-Undang tentang Perkawinan, juga mengatur tentang persyaratan umur minimal bagi calon suami dan calon istri serta beberapa alternatif lain untuk mendapatkan jalan keluar apabila ketentuan umur minimal tersebut belum terpenuhi. Mengenai masalah umur ini masih merupakan syarat materil yaitu tercantum dalam Pasal 7 Undang-Undang tentang Perkawinan, yaitu:

1. Perkawinan hanya diizinkan bila pihak pria mencapai umur 19 tahun (sembilan belas) tahun dan puhal wanita sudah mencapai usia 16 (enam belas) tahun.

2. Dalam hal penyimpangan dalam ayat (1) pasal ini dapat minta dispensasi kepada Pengadilan atau pejabat lain yang diminta oleh kedua orang tua pihak pria atau pihak wanita.

3. Ketentuan-ketentuan mengenai keadaan salah seorang atau kedua orang tua tersebut Pasal 6 ayat (3) dan (4) Undang-Undang ini, berlaku juga dalam permintaan dispensasi tersebut ayat (2) Pasal ini dengan tidak mengurani yang dimaksud dalam Pasal 6 ayat (6).

Syarat materil khusus yang berisi izin melangsungkan perkawinan dapat dilihat dalam Pasal 6 ayat (2) Undang-Undang tentang Perkawinan. Syarat-syarat formil dalam perkawinan terbagi 2 (dua), yaitu:

1. Syarat formil yang dilakukan sebelum perkawinan dilangsungkan adalah:

${ }^{21}$ Badan Penelitian dan Pengembangan HAM Kementrerian Hukum dan HAM RI, Implementasi Undang-Undang Nomor 1 Tahun 1974 tentang Perkawinan, Dalam Rangka Perlindungan Hak Asasi Perempuan dan Anak dalam Hukum Nasional dan Kovenan Internasional, hlm. 25.

${ }^{22}$ Badan Penelitian dan Pengembangan HAM Kementrerian Hukum dan HAM RI, Implementasi Undang-Undang Nomor 1 Tahun 1974 Tentang Perkawinan, Dalam Rangka Perlindungan Hak Asasi Perempuan dan Anak dalam Hukum Nasional dan Kovenan Internasional, hlm. 25.

${ }^{23}$ Adanya persetujuan bebas tanpa adanya paksaan lahir dan bathin dari pihak manapun untuk melaksanakan perkawinan, karena pada hakikatnya perkawinan mempunyai maksud agar suami dan istri dapat membentuk keluarga yang kekal dan bahagia 
Eko Rial Nugroho dan Abdul Wahid, Perkawinan Tradisi Jujuran dalam Adat Bugis Perantau di Kutai Kartangera: Suatu Kajian Perbandingan dengan Hukum Islam

a. Perkawinan harus didahului oleh suatu pemberitahuan oleh kedua calon mempelai kepada pegawai pencatat nikah (pegawai Kantor Urusan Agama untuk yang beragama Islam dan pegawai Kantor Catatan Sipil untuk yang beragama selain Islam).

b. Pemberitahuan harus dilengkapi dengan surat-surat pembuktian yang diperlukan sesuai dengan syaratsyarat yang ditentukan oleh Undang-undang untuk pelaksanaan perkawinan

c. Pelaksanaan perkawinan baru dapat dilaksanakan setelah lampau tenggang waktu 10 (sepuluh) hari terhitung dari tanggal pemberitahuan.

2. Syarat formil yang dilakukan pada saat dilangsungkannya perkawinan adalah:

a. Perkawinan dilangsungkan oleh atau dilakukan di hadapan pegawai pencatat nikah (pegawai Kantor Urusan Agama untuk yang beragama Islam dan pegawai Kantor Catatan Sipil untuk yang beragama selain Islam).

b. Perkawinan harus dihadiri oleh 2 (dua) orang saksi.

Apabila telah dipenuhi syarat-syaratnya, baik syarat materil maupun syarat formil maka kedua mempelai dikatakan telah resmi menjadi suami istri. Apabila syarat-syarat tersebut tidak dipenuhi, maka dapat menimbulkan ketidakabsahan perkawinan yang dapat mengakibatkan batalnya suatu perkawinan. Hal ini sebagaimana diatur dalam Pasal 22 Undang-Undang tentang Perkawinan yang menyatakan bahwa perkawinan dapat dibatalkan apabila para pihak tidak memenuhi syarat-syarat untuk melangsungkan perkawinan. Kompilasi Hukum Islam juga mengatur tentang rukun dan syarat perkawinan yang termaktub dalam Pasal 14 sampai dengan Pasal 38. Berbeda dengan UU Perkawinan, Kompilasi Hukum Islam membahas rukun perkawinan mengikuti sistematika fikih yang mengaitkan rukun dan syarat sahnya perkawinan.

Pada bagian kesatu Pasal 14 Kompilasi Hukum Islam menyatakan bahwa untuk Melaksanakan perkawinan harus ada: a). Calon suami; b). Calon istri; c). Wali nikah; d). Dua orang saksi; dan e). Ijab Kabul. KHI dalam persyaratan perkawinan mengikuti UU Perkawinan yang melihat syarat hanya berkenaan dengan persetujuan kedua calon mempelai dan batasan umur. Terkait dengan wali nikah, pasal-pasal dalam Kompilasi Hukum Islam menyatakan wali nikah alam perkawinan merupakan rukun yang harus dipenuhi bagi calon mempelai wanita yang bertindak untuk menikahkannya. Pasal 20 Kompilasi Hukum Islam menyatakan: a). Yang bertindak sebagai wali nikah ialah seorang laki-laki yang memenuhi syarat hukum Islam yakni muslim, akil dan baligh; b). Wali nikah terdiri dari wali nasab wali hakim.

Empat kelompok wali nasab ${ }^{24}$, pertama, kelompok kerabat laki-laki garis keturunan keatas. Kedua, kelompok kerabat saudara laki-laki kandung, seayah dan keturunan laki-laki mereka. Ketiga, kelompok kerabat paman, yakni saudara laki- laki kandung ayah, saudara seayah dan keturunan laki-laki mereka. Keempat, kelompok saudara laki-laki kandung kakek, saudara laki-laki seayah kakek dan keturunan laki-laki mereka.

Perkawinan atau pernikahan yang dilakukan tanpa adanya wali nikah dari calon mempelai wanita harus diketahui terlebih dahulu alasan-alasannya, apakah alasannya syar' $i^{25}$ atau tidak syar' $i$. Wali nikah yang menolak menikahkan calon mempelai wanita karena alasan syar'i, maka penolakan wali tersebut wajib ditaati dan kewaliannya tidak berpindah kepada pihak lain (wali hakim). Apabila calon mempelai wanita memaksakan diri menikah dalam kondisi tersebut, maka akad nikahnya menjadi tidak sah atau batil walaupun dinikahkan oleh wali hakim. ${ }^{26} \mathrm{Hal}$ ini dikarenakan, hak perwalian calon mempelai wanita tetap ada dalam diri wali nashabnya dan tidak berpindah kepada wali hakim. Dengan demikian, apabila pernikahan tersebut tetap dilangsungkan, maka pernikahan tersebut dikatakan sama dengan tanpa wali yang hukumnya batil. Hal ini sebagaimana disebutkan dalam hadits Rosullulloh SAW, "Tidak (sah) nikah kecuali dengan wali." (HR. Ahmad).

${ }^{24}$ Pasal 21 Kompilasi Hukum Islam.

25 Alasan syar'i adalah alasan yang dibenarkan oleh hukum Islam, diantaranya calon mempelai wanita telah dilamar dan belum dibatalkan, calon mempelai laki-laki orang kafir maupun fasiq dan calon mempelai laki-laki mempuayi cacat tubuh yang menghalangi tugasnya sebagai suami.

${ }^{26}$ H.A.S Alhamdani, Risalah Nikah, hlm. 90-91. 
Eko Rial Nugroho dan Abdul Wahid, Perkawinan Tradisi Jujuran dalam Adat Bugis Perantau di Kutai Kartangera: Suatu Kajian Perbandingan dengan Hukum Islam

Pada prakteknya, terdapat pula wali nikah yang menolak menikahkan anak gadisnya karena alasan yang tidak syar' $i .{ }^{27}$ Wali yang menolak menikahkan calon mempelai wanita karena alasan yang tidak syar' $i$ , maka wali tersebut disebut wali adhal. Adhal bermakna sebagai "menghalangi seseorang untuk menikahkannya jika perempuan itu telah menuntut menikah. Allah SWT berfirman dalam QS. Al Baqarah ayat 212, yang artinya:

"Maka janganlah kamu (para wali) menghalangi mereka kawin lagi dengan bakal suaminya, apabila telah terdapat kerelaan diantara mereka dengan cara yang ma'ruf. Itulah yang dinasehatkan kepada orangorang yang beriman kepada Allah dan hari kemudian diantara kamu. Itu lebih baik bagimu dan lebih suci. Allah mengetahui sedang kamu tidak mengetahui."

Wali adhal merupakan penolakan wali untuk menikahkan anak perempuannya yang berakal dan sudah baligh dengan laki-laki yang sepadan dengan perempuan itu. Jika perempuan tersebut telah meminta (kepada walinya) untuk dinikahkan dan masing-masing calon mempelai itu saling mencintai, maka penolakan tersebut menurut syara' dilarang. ${ }^{28}$ Pasal 23 ayat (1) Kompilasi Hukum Islam menyebutkan, sebab-sebab terjadinya wali hakim adalah apabila mempelai wanita tidak mempunyai wali nashab sama sekali atau tidak mungkin menghadirkannya atau tidak diketahui tempat tinggalnya. Pengertian wali hakim di dalam Peraturan Menteri Agama Nomor 30 tahun 2005 tentang Wali Hakim (selanjutnya disebut Permenag No. 30/2005), Pasal 1 angka 2 memandatkan kepada kepala Kantor Urusan Agama Kecamatan yang ditunjuk oleh Menteri Agama untuk bertindak sebagai wali nikah bagi calon mempelai wanita yang tidak mempunyai wali.

Penetapan wali hakim diatur dalam Permenag No. 30/2005, Pasal 2 ayat (1) dan (2) menyebutkan:

(1) Bagi calon mempelai wanita yang akan menikah di wilayah Indonesia atau di luar negeri/wilayah ekstra-teritorial Indonesia ternyata tidak mempunyai wali nasab yang berhak atau wali nasabnya tidak memenuhi syarat atau mafqud atau berhalangan atau adhal, maka nikahnya dapat dilangsungkan dengan wali hakim.

(2) Khusus untuk menyatakan adhalnya wali sebagaimana tersebut pada ayat (1) pasal ini ditetapkan dengan Keputusan Pengadilan Agama/Mahkamah Syari'ah yang mewilayahi tempat tinggal calon mempelai wanita.

Penggunaan wali hakim dalam praktek di masyarakat, dilakukan oleh pejabat yang oleh Menteri Agama atau pejabat yang ditunjuk olehnya untuk bertindak sebagai wali nikah bagi calon mempelai wanita yang tidak mempunyai wali. Ketentuan penggunaan wali hakim juga berdasarkan hadits sebagai berikut:

Dari 'Aisyah, Rosululllah SAW, bersabda yang artinya:

"Siapa pun diantara wanita yang menikah tanpa seijin walinya, maka nikahnya batal. Jika lelakinya telah menyenggamainya, maka ia berhak atas maharnya, karena ia telah menghalalkan kehormatannya. Jika pihak wali enggan menikahkan, maka hakimlah yang bertindak menjadi wali bagi seseorang yang tidak ada walinya". (HR. Ahmad, Abu Dawud, Ibnu Majah, Tirmidzi).

Wanita yang akan menikah, tetapi tidak ada wali yang berhak menikahkannya maka untuk mengatasi kesulitan, mempermudah dan memperingan digunakan wali hakim. Tujuannya ialah agar kemaslahatan ummat manusia dapat tercapai. Kedudukan wali hakim dalam pelaksanaan akad nikah sebagai wali pengganti dari wali calon mempelai wanita atau menggantikan kedudukan wali nashabnya yang karena keadaan tertentu tidak bisa atau tidak mau menjadi wali nikah bagi anak gadisnya. Kedudukan dan wewenang wali hakim sama dengan wali nashab atau wali yang berhak atas wanita yang berada di bawah

${ }^{27}$ Contoh alasan yang tidak syar' $i$ diantaranya berasal dari suku yang sama, keluarga miskin, bukan sarjana, bukan pejabat (pegawai), tidak rupawan.

${ }^{28}$ Wahbah al Zuhail, al Fiqh al Islami wa Adillatuhu, jilid 9, terjemahan Abdul Hayyi al-Kattani, et.al., (Jakarta: Penerbit Gema Insani, 2007), hlm. 343, sebagaimana dikutip oleh M. Solihul Fitri dalam "Analisa Pertimbangan Hakim Dalam Penetapan Wali Adhal di Pengadilan Agama Semarang (Studi Penetapan Hakim Pengadilan Agama Semarang Tahun 2013)”, diakses dari eprints.walisongo.ac.id/5523/1/102111020.pdf, 17 April 2018. 
Eko Rial Nugroho dan Abdul Wahid, Perkawinan Tradisi Jujuran dalam Adat Bugis Perantau di Kutai Kartangera: Suatu Kajian Perbandingan dengan Hukum Islam

perwaliannya. Wali hakim ini bertindak menggantikan wali nashab bagi calon mempelai wanita untuk menikahkan dengan calon mempelai laki-laki agar memenuhi persyaratan yang sah menurut hukum Islam dan harus sesuai dengan ketentuan peraturan perundang-undangan yang berlaku secara nasional.

Saksi nikah dalam Pasal 24 ayat (1) dan (2) Kompilasi Hukum Islam, menyebutkan bahwa saksi nikah merupakan rukun nikah dan setiap perkawinan harus disaksikan oleh dua orang saksi. Syarat saksi dituangkan dalam Pasal 25 Kompilasi Hukum Islam: "Yang dapat ditunjuk menjadi saksi dalam akad nikah ialah seorang laki- laki muslim, adil, akil, balig, tidak terganggu ingatan dan tidak runa rungu atau tuli." Saksi harus menghadiri akad nikah secara langsung dan menandatangani akta nikah secara langsung dan menandatangani akta nikah pada waktu dan tempat akad nikah dilangsungkan. ${ }^{29}$

Pada pelaksanaan akad nikah, ijab kabul antara wali dan calon mempelai pria harus jelas, beruntun dan tidak berselang waktu. ${ }^{30}$ Wali nikah boleh mewakilkan hak walinya kepada orang lain. ${ }^{31}$ Calon mempelai laki-laki dalam keadaan tertentu dapat mewakilkan dirinya kepada orang lain dengan syarat adanya surat kuasa dan pernyataan bahwa orang yang diberi kuasa adalah mewakili dirinya, dan, jika wali keberatan dengan perwakilan calon mempelai pria maka akad nikah tidak dapat dilangsungkan. ${ }^{32}$

Kompilasi Hukum Islam juga mengatur tentang mahar sebagai syarat sah perkawinan. Pasal $30 \mathrm{KHI}$ menyatakan: "Calon mempelai pria wajib membayar mahar kepada calon mempelai wanita yang jumlah, bentuk dan jenisnya disepakati oleh kedua belah pihak." Penentuan mahar berdasarkan atas asas kesederhanaan dan kemudahan yang dianjurkan oleh ajaran Islam. Meskipun mahar itu wajib, namun dalam penentuannya tetaplah harus mempertimbangkan asas kesederhanaan dan kemudahan. Maksudnya, bentuk dan harga mahar tidak boleh memberatkan calon suami dan tidak pula boleh mengesankan asal ada atau apa adanya, sehingga calon istri tidak merasa dilecehkan atau disepelekan.

\section{KESIMPULAN}

Tradisi jujuran adalah satu kesatuan dalam prosesi perkawinan adat masyarakat Kelurahan Kuala Samboja, Kecamatan Samboja, Kabupaten Kutai Kartanegara. Prinsip pernikahan dalam tradisi jujuran adalah pernikahan tidak akan terjadi/terlaksana atau batal, apabila jujuran tidak dapat dipenuhi oleh calon mempelai laki-laki dan keluarganya. Sementara pernikahan dalam Islam (berdasarkan UU Perkawinan dan $\mathrm{KHI}$ ), wajib memenuhi rukun dan syarat pernikahan karena rukun dan syarat pernikahan sangat menentukan sah tidaknya suatu pernikahan. Wali nikah merupakan salah satu unsur penting dalam suatu akad nikah, karena pernikahan tidak sah tanpa adanya wali. Dengan demikian, dalam hukum Islam faktor utama yang mewajibkan sah tidaknya pernikahan adalah adanya wali. Hal tersebut, berbeda dengan tradisi jujuran yang lebih mengutamakan adanya besaran jujuran yang ditentukan oleh pihak calon mempelai perempuan.

\section{DAFTAR PUSTAKA}

Buku/Artikel/Laporan

Alhamdani, HAS., Risalah Nikah Hukum Perkawinan Islam. Jakarta, Pustaka Amani, tanpa tahun. , Risalah Nikah, Jakarta: Penerbit Pustaka Amani, 1989.

Anshori, Abdul Ghafur. Hukum Perkawinan Islam. Yogyakarta: UII Press, 2011.

As-Subki, Ali Yusuf. Fiqih Keluarga: Pedoman Berkembang dalam Islam. Jakarta: Penerbit AMZAH, 2010.

Ainani, Ahmad. "Itsbat Nikah dalam Hukum Perkawinan di Indonesia”. Jurnal Darussalam, No. 2, Vol. 10, 2010.

Atabik, Ahmad dan Khoridatul Mudhiiah, "Pernikahan dan Hikmahnya Perspektif Hukum Islam". Jurnal Pemikiran Hukum dan Hukum Islam, Vol 5, No. 2, 2014.

Arpa, Ahmad Muthiee Bin, “Tinjauan Hukum Islam Terhadap 'Doi Menre' dalam Pernikahan Adat Bugis di Sarawak, Malaysia (Studi Kasus di Desa Sadong Jaya, Asajaya, Sarawak”. Skripsi Fakultas Syari’ah Dan Hukum UIN Sunan Ampel Surabaya, 2015

\footnotetext{
${ }^{29}$ Pasal 26 Kompilasi Hukum Islam.

${ }^{30}$ Pasal 27 Kompilasi Hukum Islam.

${ }^{31}$ Pasal 28 Kompilasi Hukum Islam.

${ }^{32}$ Pasal 29 Kompilasi Hukum Islam.
} 
Eko Rial Nugroho dan Abdul Wahid, Perkawinan Tradisi Jujuran dalam Adat Bugis Perantau di Kutai Kartangera: Suatu

Asyraf, Andi. "Mahar dan Paenre' dalam Adat Bugis (Studi Etnografis Hukum Islam dalam Perkawinan Adat Bugis di Bulukumba Sulawesi Selatan", Skripsi Fakultas Syari'ah dan Hukum UIN Syarif Hidayatullah Jakarta, 2015.

Ashari, Imam. "Makna Mahar Adat dan Status Sosial Perempuan dalam Perkawinan Adat Bugis di Desa Penengahan Kabupaten Lampung Selatan”. Skripsi Fakultas Ilmu Sosial dan Politik Universitas Lampung Bandar Lampung, 2016.

Arifin, Johan "Analisis Struktur Wacana dalam Acara Baantaran Jujuran di Banjarmasin". Jurnal Vidya Karya, No. 7, jilid 27, 2015.

Basyir, Ahmad Azhar. Hukum Perkawinan Islam. Yogyakarta: UII Press, 1999.

Darajat, Zakiah. Ilmu Fiqh Jilid 2. Yogyakarta: Dhana Bakti Wakaf, 1995.

Doi, A. Rahman I. Karakteristik Hukum Islam dan Perkawinan. Jakarta: Raja Grafindo Persada, 1996.

Daly, Peunoh. Hukum Perkawinan Islam Suatu Studi Perbandingan dalam Kalangan Ahlus-Sunnah dan Negara-Negara Islam. Jakarta: Bulan Bintang, 1988.

Djubaidah, Neng. Pencatatan Perkawinan dan Perkawianan Tidak Dicatat Menurut Hukum Tertulis di Indonesia dan Hukum Islam. Jakarta: Sinar Grafika, 2012.

Hikmah, Nurul. "Implementasi Pemberian Mahar Pada Masyarakat Suku Bugis dalam Perspektif Hukum Islam (Studi Kasus di Kelurahan Kalibiru Kecamatan Cilincing, Jakarta Utara)”. Skripsi Fakultas Syari'ah dan Hukum UIN Syarif Hidayatullah Jakarta, 2010.

Ikbal, Moh., "Tinjauan Hukum Islam Tentang Uang Panaik (Uang Belanja) dalam Perkawinan Adat Suku Bugis Makassar Kelurahan Untia Kecamatan Biringkanaya Kota Makassar”. Skripsi Fakultas Syari'ah Institut Agama Islam Negeri Sunan Ampel Surabaya, 2012.

Muchtar, Kamal. Asas-asas Hukum Islam tentang Perkawinan, Jakarta: Bulan Bintang, 1974.

Musfiroh, Fina. "Pemberian Peminangan yang Dijadikan Mahar (Studi Kasus di Desa Sriwulan Kecamatan Limbangan Kabupaten Kendal)”. Skripsi Fakultas Syari'ah UIN Walisongo Semarang, 2015.

Nuruddin, Aminur dan Azhari akmal Tarigan. Hukum Perdata Islam di Indonesia. Jakarta: Kencana, 2004.

Prawiro, Dimas. "Implementasi Penetapan Uang Hantaran Nikah dalam Perspektif Hukum Islam (Studi Pada Masyarakat Kelurahan Pulau Kijang Kecamatan Reteh Kabupaten Indragiri Hilir)". Skripsi Fakultas Syari’ah dan Ilmu Hukum UIN Sultan Syarif Kasim Riau, 2013.

Prodjodikoro, Wirjono. Hukum Perkawinan di Indonesia. Bandung: Sumur Bandung, 1984.

Rasjidi, Lili. Hukum Perkawinan dan Perceraian di Indonesia dan Malaysia. Bandung: Remaja Rosdakarya, 1991.

Ramulyo, Mohamad Idris. Hukum Perkawinan Islam Suatu Analisis dari Undang-Undang No. 1 Tahun 1974 dan Kompilasi Hukum Islam. Jakarta: Bumi Aksara, 1996.

Shomad, Abd., Hukum Islam: Penormaan Prinsip Syari'ah dalam Hukum Indonesia. Jakarta: Penerbit Kencana, 2010.

, Hukum Islam. Jakarta: Penerbit Kencana Media Group, 2010.

Syarifuddin, Amir. Garis-garis Besar Fiqh, Jakarta: Penerbit Kencana, 2003.

. Hukum Perkawinan Islam di Indonesia: Antara Fiqh Munakahat dan Undang-

Undang Perkawinan. Jakarta: Penerbit Kencana, 2006.

Supromo, Gatot. Segi-segi Hukum Hubungan Luar Nikah, Jakarta: Djambatan, 1998.

Sarong, Hamid. Hukum Perkawinan Islam di Indonesia: Praktek dan Prospeknya, Banda Aceh: GEI, 2015.

Sabiq, Sayyid. Fiqh Sunnah VII. Bandung: PT Alma'arif, 1981.

Soimin, Soedharyo. Hukum Orang dan Keluarga Persfektif Hukum Perdata Barat/BW, Hukum Islam, dan Hukum Adat. Jakarta: Sinar Grafika, 2004.

Sudarsono. Hukum Keluarga Nasional. Jakarta: Penerbit Rineka Cipta, 1997.

Setiady, Tolib. Intisari Hukum Adat Indonesia (dalam Kajian Kepustakaan). Bandung, Alfabeta, 2009.

Sanjaya, Umar Haris dan Aunur Rahim Faqih. Hukum Perkawinan Islam, Yogyakarta: Gama Media, 2017.

Susanto, Gatot. "Konsep Pemberian Palaku (Mahar) dalam Adat Perkawinan di Desa Pangkalan Dewa

Kabupaten Kotawaringin Barat Kalimantan Tengah (Perspektif Hukum Islam)". Skripsi Fakultas Syari'ah UIN Sunan Kalijaga Yogyakarta, 2010. 
Eko Rial Nugroho dan Abdul Wahid, Perkawinan Tradisi Jujuran dalam Adat Bugis Perantau di Kutai Kartangera: Suatu Kajian Perbandingan dengan Hukum Islam

Setiyawati, Laila Ulfah. "Pandangan Hukum Keluarga Islam Terhadap Tradisi Jujuran Pada Masyarakat Penajam Paser Utara Kalimantan Timur”. Skripsi Fakultas Syari'ah dan Hukum UIN Sunan Kalijaga Yogyakarta, 2014.

Subli. "Problematika Penentuan Jujuran di Desa Muara Sumpoi Kecamatan Murung Kabupaten Murung Raya". Jurnal Studi Agama dan Masyarakat, No. 2, Vol. 11, 2015.

Utomo, Laksanto. Hukum Adat, Jakarta: Rajawali Pers, 2016.

Yayasan Penyelenggara Penterjemah Al-Qur'an. Yaqut Al-Qur'an dan Terjemahnya Juz 1 s/d 30. Bandung: Penerbit Sinar Baru Algesindo, 2006.

\section{Peraturan Perundang-undangan}

Republik Indonesia. Undang-Undang Perkawinan Nomor 1 tahun 1974

Kompilasi Hukum Islam 